Vol 14, Issue 10, 2021

\title{
BIOCHEMICAL EVALUATION OF CHRONIC CONSUMPTION OF MONOSODIUM GLUTAMATE ON LIVER OF WISTAR ALBINO RATS
}

\author{
SURENDRA BABU THANGACHI ${ }^{*}$, VARSHA SRIRAM MOKHASI ${ }^{1}$, SHABINA KOMATH CHENOLY ${ }^{2}$
}

${ }^{1}$ Department of Anatomy, Vydehi Institute of Medical Sciences and Research Centre, Bengaluru, Karnataka, India. ${ }^{2}$ Department of Physiology, Vydehi Institute of Medical Sciences and Research Centre, Bengaluru, Karnataka, India. Email: surendra.07here@gmail.com

Received: 03 July 2021, Revised and Accepted: 11 September 2021

\section{ABSTRACT}

Objective: The objective of this study was to determine if there were any harmful effects of monosodium glutamate (MSG) on the liver of Wistar albino rats chronically at three different doses, namely, low, mid, and high doses equivalent to human consumption doses in developing countries.

Methods: The Wistar albino rats ( $\mathrm{n}=24)$ were divided into four groups, namely control, Low dose MSG (180 mg/kg), Mid dose MSG (360 mg/kg), and High dose MSG (720 mg/kg). At the end of the experimental period (120 days), animal blood was collected retro-orbitally to analyze the liver enzymes such as aspartate transaminase (AST), alanine transaminase (ALT), alkaline phosphatase (ALP), Total protein, Albumin, and Total Bilirubin in blood serum. Lipid profiles, namely, Triglycerides, low-density lipoprotein (LDL), high-density lipoprotein (HDL), and Total cholesterol were subjected to analysis using blood serum.

Results: Significant increase $(\mathrm{p}<0.05)$ in AST, ALT, ALP, and total bilirubin in serum of MSG induced low, mid, and high dose groups when compared to control group were recorded. There was a significant increase $(\mathrm{p}<0.05)$ in LDL, decrease in HDL, increase in total cholesterol and triglycerides of MSG-induced animal groups.

Conclusion: The effects of MSG on serum liver enzymes and lipid profiles in this present animal study were not severely alarming even though the dosage was chronic which opens further discussion on the controversies revolving around MSG.

Keywords: Monosodium glutamate, Lipid profile, Liver enzymes, Hepatotoxic, Low-density lipoprotein, High density lipoprotein.

(C) 2021 The Authors. Published by Innovare Academic Sciences Pvt Ltd. This is an open access article under the CC BY license (http://creativecommons.org/ licenses/by/4.0/) DOI: http://dx.doi.org/10.22159/ajpcr.2021v14i10.42819. Journal homepage: https://innovareacademics.in/journals/index.php/ajpcr

\section{INTRODUCTION}

Monosodium glutamate (MSG) is one of the most commonly known and widely used food additives throughout the world, employed in a wide variety of food flavors. Seaweed was the first source of MSG in Japan in 1908 [1]. MSG is also commercially called as Ajinomoto $\left(\mathrm{C}_{5} \mathrm{H}_{8} \mathrm{NO}_{4} \mathrm{Na}\right)$ which is the salt of L-glutamic acid and found naturally as free or bound glutamate in food proteins [2]. MSG imparts a special category of taste called as "Umami" or "Savory" or "Brothlike" or "Meaty taste" which is revolutionizing the food industry at the cost of negative effects on health [3]. In industrialized countries, the average daily consumption of MSG is around $0.3-1 \mathrm{~g} /$ day which is 2 to 3 times more in developing Asian countries [4]. Asia is one of the largest producers of MSG and steady increase in its production, which indirectly reflects the elevated consumption of MSG in humans throughout the world [5]. Most of cuisines and packaged food industries around the world invariable adopt MSG as flavor-enhancing agent. There is a lot of controversy prevailing in scientific communities regarding the safety of MSG, even though FDA marked "MSG as safe for human consumption" [6]. The Liver is one of the primary organs of the human body involved in detoxification and metabolism. Earlier studies show that administration of MSG in animals causes hepatotoxicity by altering liver enzymes such as Alanine Aminotransferase, Aspartate Aminotransferase, $\gamma$-glutamyltransferase, and bilirubin in serum as well as causing oxidative stress in the liver by depleting endogenous antioxidants such as Catalase, Superoxide dismutase and reduced glutathione [7-10]. Even MSG is most commonly employed to induce obesity models in animal studies as it modifies the lipid profile in biological systems [11-13]. Earlier studies clearly show that MSG increases low-density lipoprotein (LDL) cholesterol, triglycerides, and decreases high-density lipoprotein (HDL) cholesterol $[14,15]$. The studies examining MSG have not been able to clearly determine MSG dosage that meets human consumption geographically and as a result, many studies lack clarity in the use of food-grade MSG with route of administration other than orally [16]. Therefore, we speculated chronic use of MSG at three different doses (low, mid, and high) in animals based on human consumption of MSG in developing countries may induce hepatotoxicity biochemically.

\section{MATERIALS AND METHODS}

\section{Animals}

Adult Wistar albino rats of either sex $(n=24)$ were used for the study. Inbred rats were housed in our animal facilities at $23 \pm 1^{\circ} \mathrm{C}$ with a $12 \mathrm{~h}$ light and supplied with a temperature-adequate amount of drinkable tap water and standard laboratory chow. The rats were selected randomly for the study and acclimatized before initiating the study. Animal handling and procedural protocols were followed based on guidelines from the Committee for the Purpose of Control and Supervision of Experiments on Animals. Institutional Animal Ethical Committee (IAEC) had approved the study before initiation of the experiment with the Reg no: VIMS/IAEC/2016/03.

\section{Experimental design}

The chronic study was performed on healthy twenty-four adult Wistar albino rats. After acclimatization, the rats of either sex were assigned randomly to four groups ( $n=6$ for each group). The Group I was used as control which was fed distilled water. The Group II received MSG of $180 \mathrm{mg} / \mathrm{kg}$ body weight (Low dose). The Group III received MSG of $360 \mathrm{mg} / \mathrm{kg}$ body weight (Mid dose). The Group IV received MSG of $720 \mathrm{mg} / \mathrm{kg}$ body weight (High dose). MSG was administered daily by oral gavage for 120 days. Following the 120-day experimental period, the rats were subjected to blood collection retro-orbitally for biochemical analysis. 
Biochemical assays

The retro-orbital collection of blood in rats was performed after the completion of chronic period of animal dosing. The collected $2 \mathrm{ml}$ of blood was centrifuged at 3000 RPM for $10 \mathrm{~min}$ and serum was collected for liver function test using an autoanalyzer. The collected serum was stored in a -80 degree Celsius cold storage facility. Then the serum was subjected to assay of liver enzymes such as alanine transaminase (ALT), aspartate transaminase (AST), alkaline phosphatase (ALP), albumin, total protein, and total bilirubin. For the Liver function test, commercial kits were used and analyzed using an autoanalyser. The lipid profile analysis consisting of LDL, HDL, total cholesterol, and triglycerides were also determined from serum using an autoanalyzer.

\section{Statistical analysis}

For statistical analysis, data were processed and analyzed using Graphpad Prism software 9.1.2. The data were explicited as mean \pm standard deviation (SD). The analysis was based on one-way ANOVA and followed by Tukey's post-hoc test. Analyzed results were contemplated significant if $\mathrm{p}<0.05$. The $\mathrm{p}$-values in the current study were represented as ${ }^{*}$ for $\mathrm{p}<0.05,{ }^{* *}$ for $\mathrm{p}<0.01,{ }^{* * *}$ for $\mathrm{p}<0.001,{ }^{* * * *}$ for $\mathrm{p}<0.0001$

\section{RESULTS}

\section{Liver function test}

The liver function test results show that there was a significant $(p<0.05)$ difference between control and MSG-induced groups except for total protein and albumin (Table 1). The AST levels of MSG-induced groups were significantly $(\mathrm{p}<0.05)$ increased when compared to the control group. The MSG-induced groups exhibited significantly $(p<0.05)$ increased Alanine Aminotransferase and ALP when compared to control group. The observation of significant $(p<0.05)$ increase in total bilirubin was recorded in the MSG-induced group when compared to the control group. There is no conclusive difference statistically between MSG-induced groups and treatment groups for total protein and albumin.

\section{Lipid profile test}

Lipid profile parameters show significant differences $(\mathrm{p}<0.05)$ between control and MSG-induced groups. Triglyceride shows a significant $(\mathrm{p}<0.05)$ increase in MSG-induced groups when compared with the control group (Fig. 1). The level of HDL was significantly lower $(\mathrm{p}<0.05)$ in all monosodium-induced groups when compared with the control group (Fig. 2). All MSG -induced groups show an increase in LDL when compared to control groups (Fig. 3). The results of total cholesterol were significantly $(\mathrm{p}<0.05)$ increased in all MSG-induced groups compared to the control group (Fig. 4)

\section{DISCUSSION}

Earlier investigations similar to my findings showed that MSG causes liver damage interpreted using liver enzyme profile alterations. These investigations cannot be extrapolated to humans as those similar previous studies differed in the human equivalent dosage of MSG, route of administration and period of administration. The present study focused on the human equivalent dosage of MSG at low, mid and high dosage chronically based on average MSG consumption in developing Asian countries.
A study of liver function tests for groups induced by MSG shows that chronic administration of MSG damages liver cells. AST exhibiting $16.28 \%, 34.57 \%$ and $42.08 \%$ increase in low, mid and high MSG induced group when compared to control animals concludes that hepatic cellular damage caused by MSG. The considerable increase in ALT and ALP in monosodium induced groups were more or less similar to AST levels which reinforces that hepatocellular leakage of those enzymes due to the liver injury caused by MSG [10]. The analysis of AST and ALT enzymes for groups induced with MSG (low, mid, and

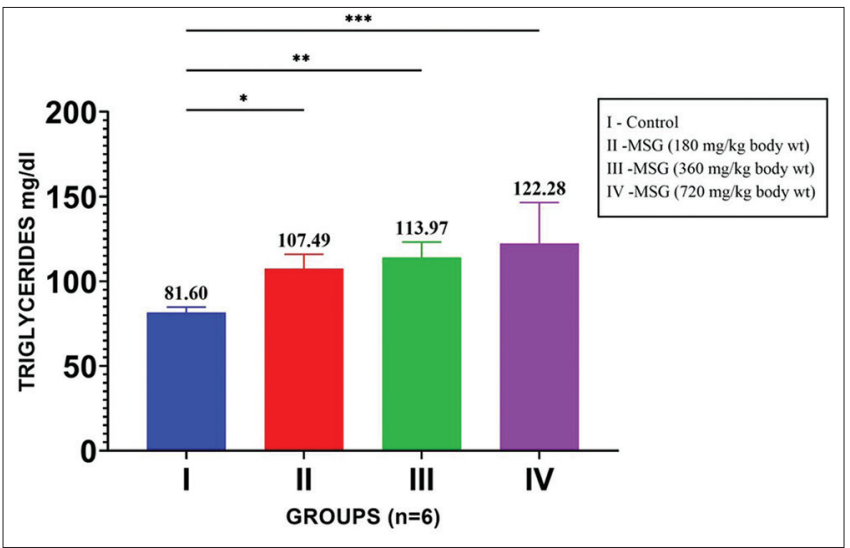

Fig. 1: Effect of Monosodium glutamate on serum triglycerides (Values are expressed as mean \pm SD. *Significantly different from the control group at $\mathbf{p}<0.05$. ${ }^{* *}$ Significantly different from the control group at $\mathbf{p}<0.01$. $* * *$ Significantly different from the control group at $\mathbf{p}<0.001$. $* * * *$ Significantly different from the control group at $\mathrm{p}<\mathbf{0 . 0 0 0 1}$ )

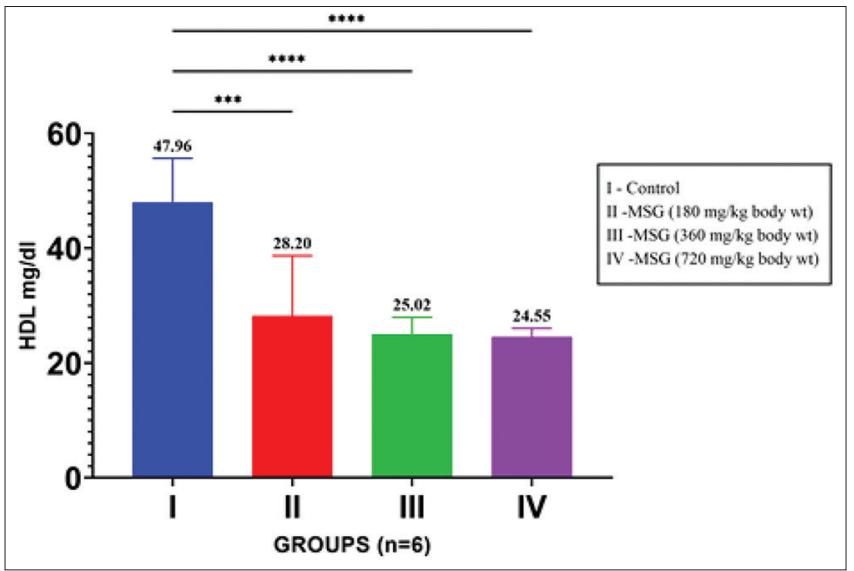

Fig. 2: Effect of Monosodium glutamate on serum High Density Lipoprotein (Values are expressed as mean \pm SD. *Significantly different from the control group at $\mathbf{p}<0.05$. ${ }^{* *}$ Significantly different from the control group at $\mathbf{p}<0.01 . * * *$ Significantly different from the control group at $\mathbf{p}<0.001$. $* * * *$ Significantly different from the control group at $p<0.0001$ )

Table 1: Effect of MSG on serum liver enzymes

\begin{tabular}{llll}
\hline Parameters & Group I (Control) & Group II (Low dose) & Group III (mid dose) \\
\hline AST (IU/L) & $91.74 \pm 7$ & $106.67 \pm 9.97^{* *}$ & $123.45 \pm 5.47^{* * * *}$ \\
ALT (IU/L) & $63.50 \pm 1.14$ & $73.30 \pm 1.89^{*}$ & $76.69 \pm 6.84^{* *}$ \\
ALP (IU/L) & $11.72 \pm 0.48$ & $13.46 \pm 1.24^{*}$ & $22.38 \pm 1.44^{* * * *}$ \\
Total Protein (g/dl) & $8.39 \pm 0.52$ & $8.72 \pm 0.78$ & $130.33 \pm 3.92^{* * * *}$ \\
Albumin (g/dl) & $4.46 \pm 0.97$ & $4.49 \pm 0.32$ & $28.30 \pm 0.88^{* * * *}$ \\
Total Bilirubin (mg/dl) & $0.27 \pm 0.03$ & $0.40 \pm 0.06^{* *}$ & $4.16 \pm 1.06$ \\
\hline
\end{tabular}

Values are expressed as mean \pm SD. $*$ Significantly different from the control group at $\mathrm{p}<0.05$. $^{* *}$ Significantly different from the control group at $\mathrm{p}<0.01$. ${ }^{* * *}$ Significantly different from the control group at $\mathrm{p}<0.001$. $^{* * * *}$ Significantly different from the control group at $\mathrm{p}<0.0001$. ALT: Alanine transaminase, AST: Aspartate transaminase, ALP: Alkaline phosphatase, MSG: Monosodium glutamate 


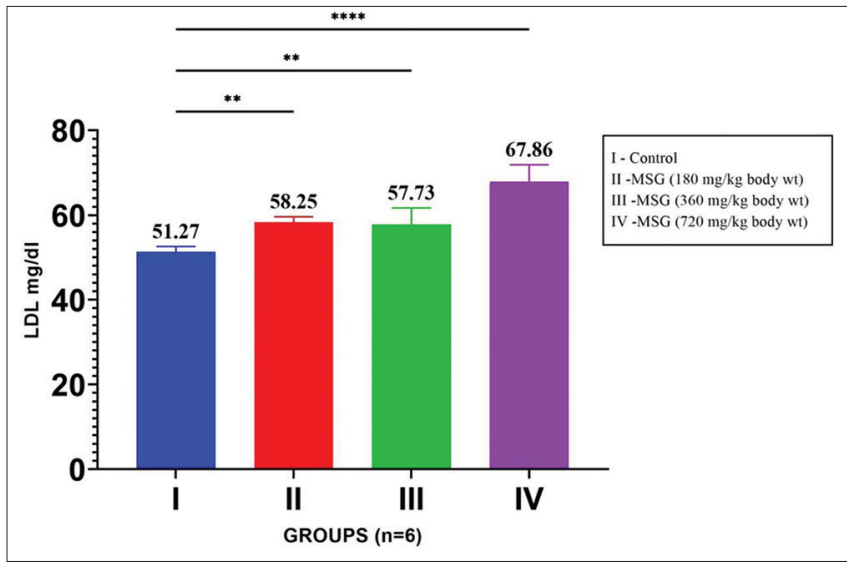

Fig. 3: Effect of Monosodium glutamate on serum Low Density Lipoprotein (Values are expressed as mean \pm SD. *Significantly different from the control group at $\mathbf{p}<0.05$. ${ }^{* *}$ Significantly different from the control group at $\mathbf{p}<0.01 .{ }^{* * *}$ Significantly different from the control group at $\mathbf{p}<0.001$. ${ }^{* * * *}$ Significantly different from the control group at $\mathbf{p}<0.0001$ )

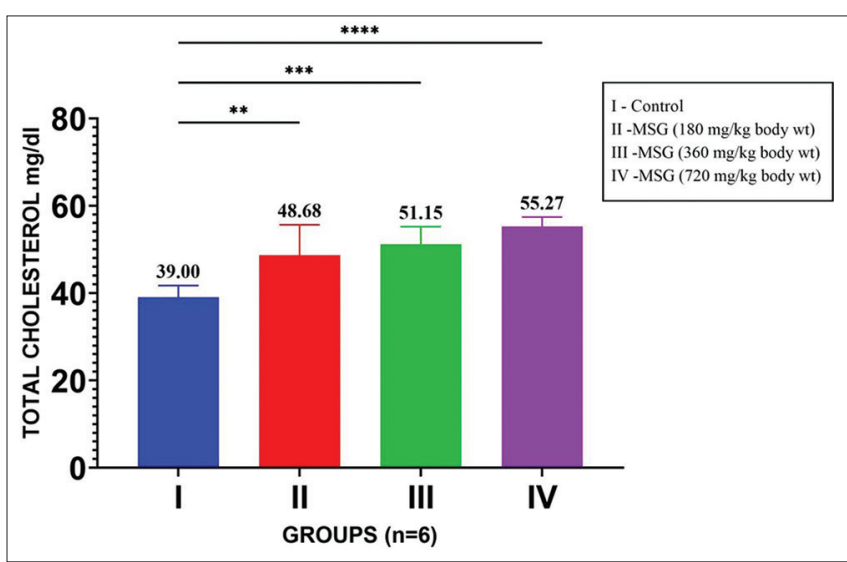

Fig. 4: Effect of Monosodium glutamate on serum Total Cholesterol (Values are expressed as mean \pm SD. *Significantly different from the control group at $\mathbf{p}<0.05$. ${ }^{* *}$ Significantly different from the control group at $\mathbf{p}<0.01$. ${ }^{* * *}$ Significantly different from the control group at $\mathbf{p}<0.001$. $* * *$ Significantly different from the control group at $\mathbf{p}<\mathbf{0 . 0 0 0 1}$ )

high doses) displays possible damage to liver cell membrane and cytosol due to monosodium induced oxidative stress which may would have triggered the hepatocytes to become leaky, releasing those liver enzymes in serum $[7,17]$. The current finidings were similar to previous studies pertaining to liver but not to the extent of severe damage. The total bilirubin altered elevation in monosodium induced groups when compared to control group may conclude dysfunctional liver cells failed to process bilirubin from the blood for bile production. The current study results show that hepatocellular damage at low dose MSG induced group is very minimal contrasting to mid and high dose MSG induced groups. These changes induced by MSG was less than 2 or 3 times in all MSG induced groups compared to control, which may indicate that liver damage was mild [18]. The reason for hepatic cell damage induced by MSG may be attributed to increased glutamate level in biological systems, which indeed stimulated Reactive Oxygen Species production either by Nicotinamide adenine dinucleotide reduction and ammonium formation [19]. Involvement of MSG in glutamine metabolism may also speculate increased glutamine altering redox status of cell by altered regulation of signalling systems in the living cell [20]. Insignificant differences in total protein and albumin may conclude that there was no alteration of total protein levels as the damage to the liver was mild.
Leaving mild liver damage untreated, can lead to Non-Alcoholic Fatty Liver Disease, Non-Alcoholic Steatohepatitis, and liver cirrhosis if the drug toxicity persists for a prolonged period of time [14].

When compared to controls, MSG significantly increases LDL in rats, indicating that it negatively affects lipid metabolism [15]. Increased LDL may indicate the presence of atherosclerotic deposits on blood vessels when MSG was chronically consumed in rats [21]. MSG consumption inducing low HDL levels in affected groups may indicate the unhealthy fat deposits in peripheral tissues and the vascular system reinforcing the high LDL levels. In accordance with previous studies, high serum cholesterol level in monosodium-induced groups as well as the increase in triglycerides of high dose monosodiuminduced groups may predict the signs of cardiovascular diseases and hyperlipidemia [17]. The erratic lipid profiles in monosodium induced group may attribute to increased $\beta$ oxidation of fatty acids, elevated 3-hydroxyl-3- methylglutaryl coenzyme A reductase [22]. The crucial role of MSG affected liver may play a vital role in the faulty increase or decrease of lipid profile parameters of rat [23].

\section{CONCLUSION}

Using the current study findings, it is extrapolated that MSG may have toxic effects on chronic consumption in rats but not to the extent of adversity. MSG safety concerns have been debated in the scientific community regularly due to the lack of thorough research and the controversies around it. In addition, more studies should be conducted to determine whether the MSG is really harming the living system adversely when consumed chronically. The future research should focus on whether harmful effects of MSG may be repairable by the body's own healing mechanisms or by natural food supplements that are part and parcel of today's lifestyle.

\section{ACKNOWLEDGMENTS}

The authors are sincerely thankful to the management of Vydehi Institute of Medical Sciences and Research Centre, Bengaluru, India for supporting us throughout to complete the research work.

\section{AUTHORS CONTRIBUTION}

Surendra Babu Thangachi designed the study, accomplished data collection, data analysis, interpretation of data and wrote the manuscript. Varsha Sriram Mokhasi guided throughout the study and was pivotal in editing the manuscript. Shabina Komath Chenoly revised the manuscript and was helpful in data collection.

\section{CONFLICTS OF INTEREST}

The authors declare that there were no conflicts of interest in this research.

\section{AUTHORS FUNDING}

Self-funding.

\section{REFERENCES}

1. Sano C. History of glutamate production. Am J Clin Nutr 2009;90:728-32.

2. Win DT. MSG-flavor enhancer or deadly killer. AU J Technol 2008; $12: 43-9$

3. Sharma V, Deshmukk RA. A fifth taste or bio bomb. Eur J Pharm Med Res 2015;2:381-400.

4. Henry-Unaeze HN. Update on food safety of monosodium 1-glutamate (MSG). Pathophysiology 2017;24:243-9.

5. Kazmi Z, Fatima I, Perveen S, Malik SS. Monosodium glutamate: Review on clinical reports. Int J Food Prop 2017;20 Suppl 2:1-9.

6. Datta A, Hossain A, Roy S. An overview on monosodium glutamate: Its direct and indirect effects. Res J Pharm Technol 2019;12:6187-92.

7. Tawfik MS, Al-Badr N. Adverse effects of monosodium glutamate on liver and kidney functions in adult rats and potential protective effect of Vitamins C and E. Food Nutr Sci 2012;3:651-9.

8. Onyema OO, Farombi EO, Emerole GO, Ukoha AI, Onyeze GO. Effect 
of Vitamin $\mathrm{E}$ on monosodium glutamate induced hepatotoxicity and oxidative stress in rats. Indian J Biochem Biophys 2006;43:20-4.

9. Eweka A, Igbigbi P, Ucheya R. Histochemical studies of the effects of monosodium glutamate on the liver of adult Wistar rats. Ann Med Health Sci Res 2011;1:21-9.

10. Nnadozie JO, Chijioke UO, Okafor OC, Olusina DB, Oli AN, Nwonu PC, et al. Chronic toxicity of low dose monosodium glutamate in albino Wistar rats. BMC Res Notes 2019;12:593.

11. Nagata M, Suzuki W, Iizuka S, Tabuchi M, Maruyama H, Takeda S, et al. Type 2 diabetes mellitus in obese mouse model induced by monosodium glutamate. Exp Anim 2006;55:109-15.

12. Bahadoran Z, Mirmiran P, Ghasemi A. Monosodium glutamate (MSG)-induced animal model of Type 2 diabetes. Methods Mol Biol 2019;1916:49-65.

13. Torrezan R, Malta A, de Souza Rodrigues WN, Dos Santos AA, Miranda RA, Moura EG, et al. Monosodium 1-glutamate-obesity onset is associated with disruption of central control of the hypothalamicpituitary-adrenal axis and autonomic nervous system. J Neuroendocrinol 2019;31:12717.

14. Lazarin MO, Ishii-Iwamoto EL, Yamamoto NS, Constantin RP, Garcia RF, da Costa CE, et al. Liver mitochondrial function and redox status in an experimental model of non-alcoholic fatty liver disease induced by monosodium L-glutamate in rats. Exp Mol Pathol 2011;91:687-94.

15. Bautista RJ, Mahmoud AM, Königsberg M, Guerrero NE. Obesity: Pathophysiology, monosodium glutamate-induced model and anti-obesity medicinal plants. Biomed Pharmacother 2019;111:503-16.

16. Zanfirescu A, Ungurianu A, Tsatsakis AM, Nițulescu GM, Kouretas D, Veskoukis A, et al. A review of the alleged health hazards of monosodium glutamate. Compr Rev Food Sci Food Saf 2019;18:1111-34.

17. Hareeri NA, Alrasheedi AA, Eassaw MM. Effect of sesame on liver enzymes and lipid profile in rats exposed to oxidative stress induced by Monosodium glutamate. J Am Sci 2017;13:71-8.

18. Johnston DE. Special considerations in interpreting liver function tests. Am Fam Physician 1999;59:2223-30.

19. Teplova VV, Kruglov AG, Kovalyov LI, Nikiforova AB, Fedotcheva NI, Lemasters JJ. Glutamate contributes to alcohol hepatotoxicity by enhancing oxidative stress in mitochondria. J Bioenerg Biomembr 2017;49:253-64

20. Matés JM, Pérez-Gómez C, de Castro IN, Asenjo M, Márquez J. Glutamine and its relationship with intracellular redox status, oxidative stress and cell proliferation/death. Int J Biochem Cell Biol 2002;34:439-58.

21. Alwaleedi SA. Adverse effects of monosodium glutamate on serum lipid profile, cholesterol status and blood glucose in adult rats. Res J Pharm Biol Chem 2016;7:732-9.

22. Okediran BS, Olurotimi AE, Rahman SA, Michael OG, Olukunle JO. Alterations in the lipid profile and liver enzymes of rats treated with monosodium glutamate. Sokoto J Vet Sci 2015;12:42.

23. Egbuonu AC, Osakwe ON. Effects of high monosodium glutamate on some serum markers of lipid status in male Wistar rats. J Med Med Sci 2011;2:653-6 